\title{
Ruští spisovatelé v Paříži
}

\author{
František Všetička (Olomouc)
}

Ruští symbolisté zcela přirozeně inklinovali k francouzské kultuře, mimo jiné proto, že Francie byla kolébkou symbolismu. Úzké pouto $\mathrm{s}$ francouzskou literaturou měl i ruský akméismus, který se ze symbolismu vydělil. Je proto zcela přirozené, že po říjnové revoluci přední představitelé ruského symbolismu a dekadence, Dmitrij Merežkovskij a Zinaida Gippiusová, emigrovali právě do Francie. Na pařížské Sorbonně pak už před první světovou válkou studoval akméista Osip Mandelštam. Ivan Bunin a Jevgenij Zamjatin jako autoři realistického zaměření měli $\mathrm{k}$ dekadenci a akméismu poměrně daleko, Francii zvolili po vítězství bolševické revoluce jako svou druhou vlast.

\section{Triády života a díla}

V lednu 1889 se Dmitrij Sergejevič Merežkovskij oženil s výstřední dekadentní básnířkou Zinaidou Nikolajevnou Gippiusovou. Stalo se tak v Tiflisu, dnešním Tbilisi, po poměrně krátké známosti. V listopadu 1901 zakládají manželé Merežkovští spolu s kritikem D. V. Filosofovem, básníkem N. M. Minským a publicistou V. V. Rozanovem Nábožensko-filozofickou společnost. V této společnosti je mimo jiné hlásána historiosofická a náboženská idea Trojice, kterou manželé domýšlejí jako ideální formu společenství, jako základní buňku budoucího lidstva. Výsledkem těchto úvah je přijetí Dmitrije Vladimiroviče Filosofova do jejich manželství, formálně se stává Merežkovského tajemníkem a okruhem známých je nazýván „třetím Merežkovským“. Jejich spolupráce se promítá i do společné tvorby, roku 1912 vychází drama Makový květ, na němž jsou jako autoři uvedeni všichni tři. Tento trojičný vztah trvá do roku 1919, kdy manželé Merežkovští trvale opouštějí sovětské Rusko; Filosofov zůstává tehdy ve Varšavě a manželé odjíždějí do Paříže. Trojúhelník je však nedlouho nato obnoven, Filosofovo místo zaujme mladý básník Vladimir Zlobin.

Tento trojičný životní program není náhodný, nebot se promítá jak do Merežkovského tvorby, tak do jeho myšlení. Dmitrij Sergejevič je především autorem trilogií, dokonce tří. První z nich dostala společný název Kristus a Antikrist a tvoří ji romány Julián Odpadlik, Leonardo da Vinci a Petr a Alexej. Druhá trilogie, Králouství $z l a$, je rovněž beletristická a představují ji díla Pavel I., Alexandr I. a Čtrnáctého prosince. Uskupení tohoto cyklu je žánrově nesourodé, nebot Pavel I. je drama, kdežto další dva tituly mají románový charakter. Třetí trilogie, tzv. egyptská, vznikla již v pařížské emigraci a má víceméně naukový, esejistický ráz. Sestává z následujících svazků: Tajemstvi tři, Zrozeni bohů a Mesiáš.

Románem o Leonardovi da Vinci, pocházejícím z roku 1901, dosáhl Merežkovskij svého uměleckého vrcholu. Už ve volbě tématu měl štastnou ruku, nebot v době jeho vrcholících tvưrčích schopností sáhl po látce netíhnoucí do ruské minulosti (kam je zaměřena celá druhá trilogie), ale po námětu evropské šíře a dosahu.

Merežkovskij je mistr kontrapunktu. V románu o Leonardovi je $\mathrm{k}$ němu kontrastem nejedna figura tohoto díla (např. Niccolo Machiavelli a Raffael Santi), v druhé trilogii je mu zjevným protějškem bázlivý a bezmocný car Alexandr I., údajný vítěz nad Napoleonem. Tento kontrapunkt je patrně vědomý, nebot román o Leonardovi da Vinci a jeho románový pandán o Alexandru I. tvoří v komponovaných trilogiích vždy jejich druhý svazek. Dřívější interpreti porovnávali a konfrontovali Merežkovského postavy v rámci jednotlivých děl nebo v rámci tematicky spjaté trilogie, případ Leonarda da Vinci a Alexandra I. však ukazuje, že nemalé vazby jdou i napříč trilogiemi. Mnohé činy a projevy Alexandra I. jsou přitom vysloveně malomyslné a karikaturní, což je výrazná protiva k Leonar- 
dovi, který je ve své tvorbě sice váhavý a trestuhodně pomalý, ale je to tvưrce, jenž ví, co chce a jednoznačně jde za svým cílem.

Merežkovského Leonardo da Vinci má v české literatuře obdobu jedině v Schulzově románu o Michelangelovi Buonarrotim (který v Merežkovského opusu rovněž vystupuje). Schulzův $K a ́$ men a bolest je ovšem významnější tím, že sehrál neobyčejně důležitou povzbuzující roli na počátku protektorátu.

Triadický charakter mají i Merežkovského odborná díla. Jeho stěžejní spis o Tolstém a Dostojevském je také trilogie, která podobně jako jeho příbuzné práce je ovlivněna filozofií Friedricha Nietzsche a Vladimira Solovjova.

Trojiční pojetí se promítá rovněž do Merežkovského náboženských představ. Klasickým dílem je v tomto směru jeho Tajemstvi tř́. Avšak triadičnost prostupuje snad celou jeho esejistiku. Merežkovskij medituje nejen nad samotným základním číslem, ale také nad jeho násobky 333 a 666. Pod zorným úhlem metafyziky hlásá tzv. Třetí zákon, jenž je předpovězen už v Apokalypse. $\mathrm{K}$ jeho zdůrazňování dochází nejen ve spisech náboženské orientace, ale také v dílech literárněhistorického a společenského zaměření. Tak např. v publikaci Duše Dostojevského, proroka ruské revoluce, praví: „V křestanstvi je Církev králoustvím nebeským, ne pozemským, duchovým, ne tělesným; v náboženstvi Svatého Ducha je církev nejenom neviditelná a mystická, ale také králoustvi viditelné, historicky skutečné, nebeské i pozemské, duchové i tělesné zároveň. To je naplněnim Třetího zákona, vtělením Třeti Božské Osoby. Pruni Osoba, Otce, se skutečně vtělila v přirozený svět prèredidský, v kosmos - druhá, Syna, se vtělila v Boha-Člověka; a stejně se Třeti Osoba, Ducha, vtěli v Bohočlověčství, v Theokracii."

Dmitrij Merežkovskij byl rovněž překladatel, ruskému publiku zpřístupňoval řecké dramatiky, zákonitě pouze tři - Aischyla, Sofokla a Euripida.

Manželé Merežkovští krátce po svém př́íchodu do Paříže otevřeli salon, jenž se stal jedním z předních center exilové kultury. Každou neděli se u nich téměř dvacet let scházeli spisovatelé všech generací. Docházelo k tomu v 16. pařížském okrese v avenue du Colonel Bonnet 11bis.

\section{Prozaička stříbrného věku}

Zinaida Gippiusová spolu se svým manželem Dmitrijem Merežkovským poprvé emigrovali do Paříže roku 1905. Vypuknuvší revoluci považovali za „přicházejícího cháma“, jak zní Merežkovského soudobý pamflet. Podruhé a tentokrát již natrvalo opustili Rusko roku 1919. Jejich novým cílem byla opět Paříž. Oba manželé tvořili nerozlučnou a navzájem se inspirující dvojici, úzce spjatou také názorově. Primární roli sehrával mezi nimi Dmitrij Sergejevič, jehož nábožensko-filozofické názory Zinaida Gippiusová nejen přijala, ale stala se také jejich šiřitelkou. A to nejen ve sdružení Zelená lampa, jež v Pařižzi založili, ale rovněž v časopise Nový koráb, jenž se stal jejich hlavní tribunou.

$\mathrm{Na}$ těsné sepětí mezi oběma tvůrci ukazuje např. báseň Zinaidy Gippiusové „14. prosince 1917“ (Posledni básnē), kterou připsala svému manželovi nepochybně záměrně, nebot' 14 . prosince (1825) vypuklo děkabristické povstání, o němž Merežkovskij právě dopisoval román (vyšel roku 1918). Gippiusové však v básni nešlo o dávnou minulost, ale o soudobé revoluční dění, jež ji - podobně jako jejího muže - naplňovalo zjitřenými obavami:

Prominou to čisti hrdinové?

Nad zradou se nesmi mlčet němě.

Ztratili jsme vǐechno svaté, nové:

$i$ stud duše i čest země.

Zradu a stud duše vyřešili manželé Merežkovští odchodem do emigrace.

Dmitrij Merežkovskij zemřel v lednu 1941, Zinaida Nikolajevna nesla jeho odchod velice těžce. Svůj bol překonala tím, že začala o svém choti psát vzpomínkovou monografii. Nedokončila ji, nebot v listopadu 1945 zemřela. Za dalších šest let vyšel Dmitrij Merežkovskij, jak je kniha nazvána, v pařížském exilovém nakladatelství.

Nad tvorbou Zinaidy Gippiusové často docházelo $\mathrm{k}$ výměně názorů o tom, zda je spíše básnírka, nebo prozaička (mimochodem psala také dramata). Její próza má nepochybně větší význam, nebot v ní dovede zachytit ty nejjemnější pocity, stavy a reakce svých postav, a to nejen ve vzájemném styku, ale také ve vztahu k promě- 
ňující se prrírodě (viz zejména povídku Jabloně kvetou).

Zinaida Gippiusová je spolu s Dmitrijem Merežkovským př́slušnicí první dekadentně-symbolistní generace, která - podobně jako v jiných literaturách - v sobě zahrnovala něco tajemného a fantaskního. Gippiusová tyto záhadné momenty promítala také do své prózy, klasickým př́íladem tajemného tématu je její povídka Fantazie, v níž vystupuje ženská bytost makropulovského typu. $\mathrm{V}$ dané próze záhadnější než u Karla Čapka.

Gippiusová má povídku Živi a mrtví, jež se odehrává v prostředí Němců, usídlených v Rusku. Stejného původu byla i její autorka, předkové Gippiusové přišli do ruské řriše už na začátku 16. století. Hrdinkou uvedené prózy je neduživá a psychicky vykolejená Charlotte, pravý opak Zinaidy Gippiusové, která v petrohradském literárním světě představovala aktivní, až výbojný živel. Projevovalo se to zejména v její literárně kritické činnosti, v níž byla až důsledně náročná. Své posudky publikovala pod mužským pseudonymem Anton Krajnij. Mužské jméno není v tomto případě náhodné, nebot i ve své básnické tvorbě se běžně stylizovala do mužské role, a to nejen v předrevolučním symbolistním období, ale také v dobách pozdní pařížské emigrace:

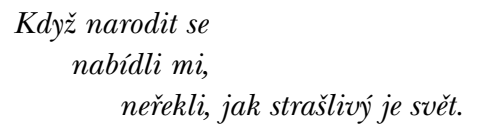

\section{Mohl jsem}

snad

smlouvat s nimi?

A ted' jen - domů! domů! zpět!

V próze Zinaidy Gippiusové se objevuje řada neběžných a zcela nezvyklých témat. Navíc témat, jež jakoby předbíhala svou dobu. Povídka Já ho zabil je např. ryze kafkovská, pochopitelně zahalená do ruského rubáše. Označovali-li Zinaidu Gippiusovou za dekadentní madonu, čarodějku a d'áblici, pak její prózy ukazují, že se tak dálo právem.

K zvláštním tématům Zinaidy Nikolajevny patři problematické závislosti mezi sourozenci nebo mezi synem a matkou. Jde o vztahy až cho- robného rázu, jež většinou končí deziluzívně. Nepřirozenou spjatost bratra se sestrou zachytila v povídce Jedna bytost (oba sourozenci se chápou jako jedna nerozborná bytost), synova závislost na matce a matčina na něm je posléze námětem povídky Jabloně kvetou. $\mathrm{V}$ obou prózách jde o neobvyklé psychické, až patologické př́ípady.

Gippiusová je mistryní ve sféře povídky a novely, kdežto v románech (konkrétně ve Zlatokvětu) upadá do rozbředlého a rozvláčného sentimentu a do nevěrohodných situací, jež jsou tak vzdáleny vnímavosti a námětové neotřelosti jejích drobných próz.

Do symbolistické generace, jejíž éra bývá považována za stř́íbrný věk ruské literatury, patřili vedle manželů Merežkovských dále Konstantin Balmont, Vjačeslav Ivanov, Alexandr Blok a Andrej Bělyj. Všichni patřili mezi přátele Merežkovských, v Petrohradě navštěvovali jejich pověstný literární salon. Balmont a Ivanov podobně jako oni emigrovali, Bělyj a zejména Blok naopak bolševickou revoluci uvítali. Alexandr Blok tak učinil v poemě Dvanáct, v níž vedle dvanácti revolucionářů vystupuje také Ježíšs Kristus. Zinaidu Gippiusovou jejich čin do krajnosti rozhořčil, své zklamání vložila do básně Šel, jež končí tímto čtyřverším:

Roucho plesá a mráz věje

od severu ulicí...

Nikdy Kristus nenajde je -

dva ztracené, bloudicí.

\section{Budoucnost v minulosti}

Jevgenij Zamjatin byl celým svým založením skeptik. Carská éra, tak, jak ji ve svých prózách nahlížel, byla nesmyslná, sovětská pak ještě nesmyslnější. Co tyto jeho postoje vyvolalo, je obtížné stanovit. Určitou roli v nich nepochybně hrálo prostředí, v němž se narodil (světlo světa spatřil v Lebed’ani u Charkova roku 1884). Rozhodující úlohu však sehrálo samotné Rusko, zaostalé a barbarské, jež zachytil např. v novelách Zapadákov a Psíživot. Animozitu proti společenskému dění po Řijnové revoluci si Zamjatin patrně odnesl už ze své práce v bolševické frakci 
sociálně demokratické strany za svých mladistvých let, za niž byl pronásledován a nakonec uvězněn. Tím se jeho sympatie $\mathrm{k}$ tomuto hnutí navždy vyčerpaly, což se plně projevilo po roce 1917 jak v jeho společenském konání, tak v jeho literární práci. Nakonec pak vyvrcholilo odchodem do emigrace.

Zamjatinovo zpodobování carské a sovětské éry je při rozlišování mnohdy neznatelné, nebot své osobní problémy, hluboce osobní, si jeho hrdinové nosí v sobě a musí si je prožít a odžít v kterékoliv době. Odehrává-li se Sofiin příběh z novely Vysoká voda v sovětském období, je to $\mathrm{v}$ podstatě zcela jedno, stejně tak by mohl probíhat před velkým Řijnem. Zamjatin obě tato údobí vidí shodně a téměř nerozlišitelně, jeho životní osud a jeho zakazovaná tvorba však jednoznačně ukázaly, že horší bylo to, co nastalo potom.

Zamjatin nejenže nevede podstatný rozdíl mezi Rusí carskou a sovětskou, ale stejný primitivismus a společenskou ubohost shledává i v prostředí anglickém, kam byl za první světové války jako lodní konstruktér vyslán carskou vládou stavět ledoborce. Anglická společnost se mu jevila stejně ubohá jako ta domácí, jak ukazuje zejména povídka Lovec duší.

$\mathrm{V}$ některých svých prózách vytváří Zamjatin bizarní, nepochopitelný, deformovaný svět (např. v povídkách Jeskyně a Mamaj, obě z roku 1920). Už z roku 1920, nebot nastavují křivé zrcadlo vznikajícímu sovětskému režimu. To je ovšem pouze jedna stránka věci, druhá je neméně komplikovaná, nebot Zamjatin nahlíží tento svět velice podivnýma očima, jeho svět je nejen nesmyslný, ale je také bizarně podáván. Je to perzifláž sovětského bytí, která si v deformaci a obtížně dešifrovatelné nesrozumitelnosti libuje. Zamjatinův svět je nepříčetný a obdobně je nazírán a zobrazován. Neplatí to ovšem pro celé jeho dílo, nebot jeho rané práce a některé pozdní se tomuto zpo̊sobu zobrazování zcela vymykají.

Jevgenij Zamjatin se proslavil zejména výstražnou antiutopií $M y$, napsanou už roku 1920, která mohla vyjít jedině v překladech v zahraničí. Autor v ní zachycuje zautomatizovaný rov- nostářský svět budoucnosti, jakýsi model příští komunistické společnosti. Další vývoj naší spotřebitelské society však ukázal, že Zamjatin viděl daleko dál.

V souvislosti se Zamjatinem se často hovoří o tzv. ornamentální próze a o realistickém symbolismu (o tvorbě na rozmezí mezi realismem a symbolismem). Touto metodou, tou symbolizující, je kupř. napsána Povidka o tom nejhlavnĕjšim. Pro metodu je příznačný přerývaný, zámlkový způsob záznamu, plný nedopovězení. Mnohé závažné události autor pomíjí, na druhé straně si libuje v symbolických postavách a v symbolice vůbec. Je docela možné, že v Povídce o tom nejhlavnějšim se $\mathrm{k}$ této metodě uchýlil zejména proto, aby zastřel její myšlenkové zaměření (pro autora tak nebezpečné na začátku sovětské moci). Próza totiž pojednává o střetu dvou protikladných sil, sovětské a antisovětské; Zamjatinovy sympatie jsou v ní na té údajně „nesprávné“ straně.

Jevgenij Zamjatin byl rovněž esejista, kritický a pronikavý esejista. Roku 1921 ve stati Bojim se s obavami výstražně napsal: „... bojím se, že ruská literatura má jen jedinou budoucnost - svou minulost."

Za obdobné názory jej posléze stihl zákaz publikování. Zamjatin se obrátil dopisem př́imo na Stalina s žádostí o vycestování na západ. Tuto žádost výrazně podpořil Maxim Gorkij, takže na sklonku roku 1931 mohl vycestovat. Jeho první zastávkou byla Praha, kde pobyl asi tři měsíce a přednesl také jednu přednášku. Bedřich Václavek, jinak tolerantní marxista, při této př́ležitosti o něm napsal: „К̌íjnovou revoluci skončila pro něho kulturni historie lidstva a začiná doba predkulturni. Jeho rekové v ni ztráceji své lidství, všecko kulturni z nich padá a objevuje se člověk jeskynni, zviřecky egoisticky" (Tvorba, 1932). Václavek míní tato slova jako odsudek, nepochybně ovlivněný kampaní, která byla proti prozaikovi v Sovětském svazu vedena. Podíváme-li se na kritikovo tvrzení s nadhledem a odmyslíme-li si dobový polemický postoj pisatele, pak ve své podstatě odpovídá Zamjatinově literární skutečnosti, jež - žel - nebyla v rozporu se skutečností sociální. 
Z Československa odjel Zamjatin do Paříže, kde po pěti letech pobytu skonal 10. 31937. Naděžda Melniková-Papoušková uveřejnila ještě v témže měsíci v Lidových novinách nekrolog, v němž mimo jiné uvedla, že zemřelý s francouzským prostředím nijak nesrostl a jediná země, kde chtěl žít a kde se cítil dobře, bylo Československo; na sklonku svého života projevil prý přání stát se československým občanem.

V Paříži Zamjatin bydlel - podobně jako Merežkovskij, Gippiusová a Bunin - v 16. okrese, konkrétně v rue Raffet 14 . Zde také zemřel.

\section{Temný nostalgik}

Prostředí, do něhož se narodíme, velmi často natrvalo ovlivní náš život. Tato deviza velkou měrou platí i pro Ivana Alexejeviče Bunina. Narodil se ve středoruské Voroněži (v říjnu 1870), stejně tak jeho neúspěšná gymnaziální studia a první zaměstnání jsou spjata se střední Rusí. Tato oblast, její obyvatelé a především její příroda trvale vstoupili do autorovy tvorby v celém jejím rozsahu, tj. v období ruském i v údobí emigračním, francouzském. Bunin prrišel na svět $\mathrm{v}$ rodině zchudlého venkovského šlechtice, což se rovněž promítlo do jeho díla, nebot' stesk a nostalgie za prostředím, které nenávratně mizelo a říjnovou revolucí bylo beznadějně smeteno, se stalo jedním z dominantních témat jeho próz.

Stesk, téměř vše je u Bunina stesk za odcházejícími statkářskými časy, stesk za mizící starou Rusí. Jedna z jeho raných povídek se jmenuje Antonovská jablka, a už tam to všechno je, zakleto a vypovězeno. A v celém dalším díle se tento pocit vrací a opakuje. Tematika Buninových próz je pochopitelně širší, nostalgie za ztracenými a nenávratnými časy v nich však přetrvává až do závěru jeho tvorby.

Buninovy povídky a novely mají převážně oslabený syžet, dějová složka je u něho nerozvitá, což nepochybně souvisí s autorovým lyrickým chápáním světa. V některých případech sleduje a zaznamenává pouze náladu, dojem, pocit (Sekácii, Noc, Pozdni hodina). Jindy zachycuje nevzrušivé až banální dění, jež zakončí nečekaným a nesmyslným zvratem (Uši jako smyčky, Heinrich).
Ivan Bunin začínal jako básník, první sbírku vydal už roku 1891. Poezii psal sice celý život, znám se však stal především jako prozaik. Do širšího povědomí se dostal románovým pokusem Vesnice, v němž naprosto popřel dosavadní narodnické iluze o venkovském člověku jako základu ruské společnosti a nemilosrdně naopak ukázal na barbarství, brutálnost a zaostalost ruské vesnice. Buninova románová novela měla pronikavý ohlas, autor se svojí Vesnicí zařadil mezi přední spisovatele Ruska. Vřele tuto prozaickou práci uvítal zejména Maxim Gorkij. Vesnice vyšla roku 1910, Bunin měl tehdy rovných čtyřricet let.

Roku 1933 získal Nobelovu cenu za literaturu, stal se tak prvním ruským spisovatelem, jenž toto vyznamenání obdržel. Nobelovu cenu obdržel za svůj román Život Alexeje Arseñjeva, $\mathrm{v}$ podstatě jediné románové dílo, jež vůbec napsal (zmíněná Vesnice je víceméně náběhem na románový tvar). Námětové podloží Života Alexeje Arseñjeva je sice autobiografické, ale zdaleka se neomezuje pouze na autorův vlastní život. Je to lyrickoepická historie nejen jeho rodu, ale také všeobjímající obraz ruské společnosti a ruské př́írody. Částečným paradoxem je, že Nobelovu cenu dostal za neúplný román, nebot̉ jeho poslední část, pátá, nazvaná Lika, nebyla v té době ještě dopsána, knižně vyšla teprve roku 1939. Kompletní Život Alexeje Arseñjeva pak až roku 1952. Buninova Nobelova cena spadá tedy do jeho emigračního období, nebot roku 1920 spisovatel navždy opustil tu zemi, kterou celý život opěvoval.

Projevem Buninova pozdního mistrovství je nejen Život Alexeje Arseñjeva, ale také sbírka povídek Temné aleje, kniha milostných historií. Je to ve světové literatuře snad jediný povídkový soubor s tématem milostných příběhů, a jak napovídá titul sbírky, jde o lásky nenaplněné, nedovršené a často končící smrtí. O Buninovi se ostatně často uvádí, že věčným námětem jeho próz jsou láska a smrt. U něho obě tyto lidské konstanty jako by souvisely, jako by se prritahovaly. Vedle Temných aleji se tato tematická tendence plně projevuje také $\mathrm{v}$ autorově vrcholné novele Mitova láska, jež podobně jako povídkový soubor vznikla v jeho emigračním období. 
Konkrétně v Př́ímořských Alpách, v městečku Grasse, kde se svou manželkou trávili sluneční letní měsíce (zimu pak prožívali v Paříži).

Bunin má smysl pro rytmus a harmonii svých próz, což nepochybně souvisí s jeho muzikálním talentem. Relativně pravidelný rytmus má povídka Čangovy sny, v níž se stř́ídají snové scény psa Čanga z dávné minulosti, která byla plna spokojenosti a životní plnosti, s přítomnými výjevy, v nichž převládá ubohost, trýzeň a posléze smrt jeho pána. Bunin považoval tento druh próz za prózy symfonické.

K Buninovým oddaným žákům patřil Valentin Katajev, který ve své memoárové knize Tráva zapomněni líčí svá setkání s prozaikem v Oděse ještě v době, než do jejich bran vstoupily oddíly rudých. Často mezi sebou hovořili o Buninově tvorbě, mimo jiné i o jeho symfonických prózách, $\mathrm{k}$ nimž př́íslušela také nedávno publikovaná novela Pán ze San Franciska. Význam Katajevových vzpomínek spočívá především v tom, že v nich zaznamenal některé z podstatných Buninových myšlenek; o uvedené próze a o symfoničnosti v ní tehdy řekl: „Hlavni préece je, co jsem v Pánovi ze San Franciska rozvinul - totiž cit pro symfoničnost, který je v nejuyššim smyslu slova vlastni každé duši na světě, stavba umělecké prózy, budovaná více na hudebnich než logických základech, prózy, v niž se měni rytmus, v niž jsou variace, prechody z jednoho hudebniho kliče do druhého, prostě jde o kontrapunkt, jaký se do jisté miry pokusil využit Lev Tolstoj ve Vojně a miru: smrt Volkonského a podobně.“

Zmínka o Tolstém není náhodná, nebot jeho názorovému světu Bunin v mladém věku silně podléhal. Změnil v té době dokonce zaměstnání a stal se pod vlivem Tolstého učení bednářem. Autor Vzkřǐšni v něm však rozpoznal nevšední talent a doporučil mu, aby se vrátil k literatuře.

V Pařiži žil Ivan Bunin v rue Jacques Offenbach č. 1 , ve čtvrtém patře. Tam také 8 . listopadu 1953 skonal.

\section{Z Paříže do Druhé říčky}

Začátek a konec básnické tvorby Osipa Mandelštama je jakoby spjat s Francií. V letech 1907-1908 pobýval mladý Mandelštam v Pařiži a nejspíše v tomto období začal psát také poezii, nebot jeho nejstarší verše pocházejí z roku 1908. V Zábranově výboru z Mandelštamovy poezie nazvaném Ruská Tristia nese poslední báseň datum 3. 3. 1937 a básník ji věnoval Francii:

Jak o soucit a milost prosím dnes

o tvou prst', Francie, a o tvi̊j zimolez,

o pravdu tvých hrdliček a krìdu zakrslých, ztracených vinařo v ohradách tylových.

A v mírném prosinci i tvioj vzduch přistřižený

- zámožný, dotčený - se jinovatkou pění...

Osip Mandelštam za svého pařižského pobytu studoval na Sobonně, mimo jiné poslouchal přednášky Henriho Bergsona. Současně sledoval soudobou francouzskou literaturu, poezii symbolistů a tvorbu prokletých básníků. Dva semestry pak strávil v Heidelbergu, kde studoval starou francouzštinu a starou francouzskou literaturu. Z francouzských a německých učitelů na něj nejvíce zapůsobil Henri Bergson, ještě po letech se na něj odvolával ve svém eseji O podstatě slova.

Do sorbonnských učeben neměl Osip Mandelštam daleko, nebot bydlel přímo v rue de la Sorbonne 12, v ulici, kde stojí řada univerzitních budov. Dům, v němž Osip Mandelštam dlel, měl už básnického ducha, nebot' v letech 1890-1891 v něm bydlel portugalský básník António Nobre. Mezi oběma básníky je jistá shoda, nebot v době, kdy Portugalec Nobre poznával Paříž, se Mandelštam právě narodil (15. 1. 1891). António Nobre, podobně jako Osip Mandelštam, patří $\mathrm{k}$ básníkům tragickým, zemřel v třiatřiceti letech na tuberkulózu.

Výše citovaná báseň není jediná, jež má francouzský podnět, řadí se k ní také Mandelštamova báseň Impresionismus, která byla nejspíše inspirována Monetovým obrazem Šeřrk na slunci:

Malǐr nám štětcem předvést chtěl

šeřiky mdlobně rozvonèlé

a barvy jako schůdky znělé

na plátno v strupech nanášel.

Oslnivost francouzskými malíri není u Mandelštama ojedinělá. V roce 1930 navštívil Arménii, své dojmy zachytil v „polorománě“ Putování 
do Arménie; během této cesty zavítal do muzea, kde zhlédl díla předních francouzských malírů. O Monetovi se v této próze zmínil jen stručně: „Každá mistnost má svou atmosféru. $V$ mistnosti Clauda Moneta cítite vĩni řeky." Ostatní Francouze charakterizoval nejen obšírněji, ale především dosti osobitým způsobem, připomínajícím surrealistické zmocňování se světa. Vincenta van Gogha nazírá např. takto: „Van Gogh chrli krev jako sebevrah z laciného hotelu. Prkna podlahy v nočni kavárničce se vzpinaji a ubihaji jako žlab v elektrickém běsněni. A úzké necky biliáru připominaji rakev. - Ještě nikdy jsem se nesetkal $s$ tak štěkavým koloritem. - A jeho zahradni konduktérská krajinka! Jako by z ni prèed chvilkou utřeli mokrým hadrem prach z dýchavičných lokálek. - Jeho plátna, na nichž je rozmatlána vaječnice katastrofy, jsou názorná jako školni pomůcky - mapy z Berlitzouy školy.“

Osip Mandelštam byl nejen vykladačem francouzských malířu, ale především básníků. Napsal studii o Villonovi, Chénierovi a Barbierovi. Z trojice jmenovaných mu byl nejbližší Auguste Barbier, básník pařížské revoluce 1830. Mandelštam překládal jeho Jamby a navíc se jimi nechal inspirovat $\mathrm{k}$ veršům příbuzného ladění, v nichž znovuožívala Paříž jeho studentských let:

Spiš dlažbě rozumím než rěci holubičky.

Kostky jsou holubi, domy jak holubnićky, podkovy potokem zde vyzváněji zvěst po zvučném dlážděni té prababičky měst.

Zde po událostech vždy dèti hladovèly, vrabčáci Pařiže, jak do vrabců když střeli, zde sezobávali zrnitý střelný prach, frygickou prabábou rozsypávaný hrách, zde zapomenutá rozinka vzduchem leti, proutěný košičck se vrývá do paměti,

a domy stěsnané - mličñáci v sanici $v$ stařeckých čelistech stoji jak bratřici.

Osip Mandelštam překládal vedle Barbiera také Racina a starofrancouzskou epiku. Naděžda Mandelštamová, básníkova manželka, ve svých vzpomínkách poznamenává: „Nedávno našel Saša Morozov v jakémsi archivu Mandelštamovu parafrázi Pláče o Alexejovi a Aliscanse. V obou věcech, které vskutku nejsou pouhým překladem, se podivně prosadil hlas osudu. A Mandelštam to cítil. Alexej byl bytostným zaslibenim se bidě, zatímco prostřednictvím Aliscanse jako by O. M. př́sahal, že se nebude schovávat, když bude třeba hájit život."

Osip Mandelštam patřil spolu s Nikolajem Gumiljovem a Annou Achmatovovou k akméistům, kteří krátce před první světovou válkou vstoupili do ruské poezie. Vystoupili dosti rázně proti symbolistům, s nimiž měli však jedno společné - orientaci na světovou kulturu. Osip Mandelštam prosazoval tuto orientaci mezi akméisty nejúsilovněji.

Ve výše citované básni Jak o soucit a milost prosím dnes... je poloverš „Fialka však $i$ vězněná...“ Osip Mandelštam jako by těmito slovy přivolával vlastní smrt, jejíž blízkost si uvědomoval. Už v první polovině třicátých let byl čtyři roky internován a po krátkém období svobody byl znovu zatčen. Zemřel pravděpodobně 27. 12. 1938 ve sběrném trestaneckém táboře Druhá říčka u Vladivostoku. Příčina smrti - vysîlení nebo skvrnitý tyf. Zahynul nedosáhnuv čtyřicátý osmý rok svého života.

Známí Osipa Mandelštama dotvrzují, že básník si na svých procházkách tiše memoroval verše své a verše oblíbených básníků. Který pronášený verš byl asi v Druhé říčce jeho veršem posledním?

\section{doc. PhDr. František Všetička, CSc.}

Olomouc, Česká republika

fvseticka@seznam.cz 